\title{
Kidlat Tahimik, Cosmo(s)polit: An Introduction
}

Tilman Baumgärtel

The way Kidlat Tahimik tells it, it was all cosmic fate-how he, the Philippineborn, Wharton-trained Master of Business Administration graduate, became an independent filmmaker in Munich. How he swapped the fashionable clothes that he wore in Paris as an economic adviser at the OECD for long hair and Bavarian lederhosen that he wears to this day, his apartment in the 4. Arrondissement for a commune in rural Bavaria, the reputation that he gained with his debut film The Perfumed Nightmare (1977) for the familiarity of the art scene in his home town Baguio in the Cordillera Mountains in the North of the Philippine main island Luzon. And-one might add-how he, an autodidact as a director, developed a completely individual style not just of film making, but also of film production per se.

In the case of Kidlat Tahimik, that does not mean that his films are highbrow, elitist or taxing to watch. "Avantgarde" in this sense he is not, and if he breaks the rules of traditional film making, it is not out of contempt for them, but rather out of an innocent naiveté. His films are so full of playful humor and lovingly sculpted details, of a sense of family and a high respect for the way completely ordinary people can be completely extraordinary, that they do not exclude any viewer. In fact, the most appreciative audience for the underdogs who star in films like The Perfumed Nightmare, Turumba, or Memories of Overdevelopment might be children.

Given the scope of the cosmic intervention that Kidlat Tahimik allowed in his life and the international upshots of his works, the designation 
"Cosmo(s)politan" might be fitting. As such he has created a unique and outstanding body of work not just as the first independent filmmaker in Southeast Asia, but also as a performance and installation artist, occasional writer, architect of his own residence, activist, and role model for a whole generation of young filmmakers in the Philippines. (Acceptance of external forces on his existence did not include his name, however: he fought in court for the right to have his self-chosen moniker "Kidlat Tahimik," Tagalog for "Quiet Lightning," rather than his given name Eric de Guia-in his official documents.)

Without a formal film education and largely outside the world cinema milieu, Tahimik has since the end of the 1970 s created a completely unique and completely unrivalled oeuvre, which has yet to be discovered by the art film world at large. Even though he has explicitly denied any connection of his work to the "Third Cinema", his films nevertheless share many traits with the films of the Latin-American directors of the 1960s and '70s that combined opposition against the exploitation of the so-called Third World with a rebellion against conventional film forms. Unlike the films of directors such as Octavio Getino and Fernando Solanas however, Kidlat Tahimiks films are free of the Marxist rhetoric and the pathos that are characteristic of films like La hora de los Hornos and that make them appear so dated today. Because Tahimik renounces simple slogans, but rather deconstructs and redefines the symbols and the rituals of colonialism, his criticism of it is all the more striking. It is precisely because Kidlat Tahimik refrains from lectures and angry polemics, that he is able to convey his ideas so persuasively-and it is therefore fitting that the education of his three sons turned into an all-embracing artistic project in itself.

While he was born in 1942 in the Philippines, he didn't begin his career in his home country, but in Germany in the early 1970s, where he was supported by Werner Herzog, among others, and shot his first film, The Perfumed Nightmare in Paris and Munich-on expired film material from students of the Munich Filmhochschule that he had edited on editing tables that kind souls let him use for free. The result was the surprise success of the Berlinale in 1977 and a cult movie of the "New Social Movements" of that time. It got released theatrically in Germany (most likely, the first time a director from the Philippines got his film into German cinemas), and lent its name to the temporary cinema of a Berlin squat in the early 1980s. His connection to Germany continued after he returned to the Philippines: parts of his film Who Invented the Yoyo? Who Invented the Moon Buggy? (1982) were shot in rural Baravia and his globalization parable Turumba (1983) was commissioned by German public television station ZDF. 
In films like these, Kidlat Tahimik anticipated the economic and cultural globalization of the present and commented on it from the point of view of the "global South." The American literary scholar Fredric Jameson has described Perfumed Nightmare as a Jeepney "that ferries its way back and forth between First and Third Worlds with dignified hilarity" in his book The Geopolitical Aesthetic: Cinema and Space in the World System. (Jeepneys are Philippine minibuses, originally constructed out of American military jeeps, which were left behind by the US Army after the end of the Second World War-in a way, they themselves are a metaphor for the many crosscultural hybrids that are so characteristic of the Philippines.)

Like these minibuses, Kidlat Tahimik's films are adventurous hybrids and resourceful means of transport between the Global South and the rest of the world. They have become vital testimonies of a cinematic dialogue between these spheres and make Tahimik one of the most important representatives of the postcolonial cinema, to which he has added highly individual facets.

But Tahimik's films are by no means just "messages from the Third World," as a German reviewer called The Perfumed Nightmare on the occasion of his premiere at Berlinale. They are both reflection and result of a world that has been globalized down to the most intimate details of our private lives. Whether Kidat Tahimik lets a tropical Jeepney drive through the streets of Paris, Munich and Weilersheim, whether he lets a tyrannical German business women turn a small hamlet in Luzon into an souvenir sweatshop, whether he narrates the travels of Magellan from the perspective of his slave, or whether he himself plays the nose flute as an "Indio" in a travelling circus in Werner Herzog's Jeder für sich und Gott gegen alle. he provides a vexed but highly instructive perspective of the Global South towards the so-called "First World": The Philippines lookS to Europe, and thus comeS up with narratives and images that no European filmmaker would be able to.

Since Kidlat Tahimik has left his international reception to the forces of the cosmos, his international reputation relies largely on his first film, The Perfumed Nightmare, that is distributed in the US by Francis Ford Coppola's Zoetrope Pictures, and in Europe by the Arsenal film distribution. While The Perfumed Nightmare as well as his other films are currently not available on DVD and online, Perfumed Nightmare and Turumba only recently became available for streaming at Amazon Prime, and his comeback film Balikbayan No.1 from 2015 that travelled to a number of festivals was the first contact that many cineastes have had with his work.

So far, one has to turn to the murkier parts of the internet to find the majority of his films - that include five feature-length films, one documentary and a number of shorter video diaries and film essays-as they are not commercially available. There is also hardly any literature on 
the director, apart from some scattered interviews and a handful of essays. The purpose of these interviews with him and his wife and collaborator Katrin de Guia, therefore, is to provide reliable, firsthand information on a director that is far too little known internationally and outside of highly specialized circles.

To provide an overview of his oeuvre, we organized a retrospective of his complete works in April 2016 in the Berlin cinematheque Arsenal that drew a sizable audience and substantial coverage in the press and specialized film magazines. This book has grown out of this retrospective. We took advantage of the fact that Kidlat Tahimik was in Berlin for the whole duration of the retrospective to do a number of in-depth interviews with him that cover his entire body of work. In combination with statements from the conversations with the audience these interviews make up a good part of this book, to provide the reader with the opportunity to get Kidlat Tahimiks point-of-view first hand. We also conducted an interview with Kidlat Tahimik's wife Katrin De Guia, who-as costume designer and as occasional performer-has contributed to his films and who has been an active partner in Kidlat Tahimiks political and cultural activism.

I am happy that these long and thorough discussions of Kidlat Tahimik's work are now available online in Plaridel, the review of the Film Institute of the University of the Philippines where I taught from 2006 to 2009. I am particularly grateful to Patrick Campos that he let me convince him to publish these interviews despite their considerable length. We tried to cover all the aspects of the work of Kidlat Tahimik that have previously only been covered separately here and there.

Here's hoping that this publication reminds the world and the cosmos of the completely unique oeuvre that the Cosmo(s)polit Kidlat Tahimik has created in a career that spans more than four decades, and that it motivates some of the inhabitants of this cosmos to watch his extraordinary films.

TILMAN BAUMGÄRTEL is a Professor for media studies at the Hochschule Mainz in Germany. He taught at the Film Institute of the University of the Philippines from 2005 to 2009. His publications include Kino Sine. Philippine-German Cinema Relations (2007) and Southeast Asian independent Cinema (2012). (corresponding author:mail@tilmanbaumgaertel.net) 